\title{
Sustainable production of protein of animal origin - the state of knowledge. Part 1. Resources and emissions as factors affecting sustainbility
}

\author{
G. Flachowsky and U. Meyer ${ }^{1}$ \\ Institute of Animal Nutrition, Friedrich-Loeffler-Institut (FLI), Federal Research Institute for Animal Health \\ Bundesallee 50, 38116 Braunschweig, Germany
}

KEY WORDS: sustainability, protein of animal origin, edible protein, resources, gas emissions, carbon footprints

Received: 19 September 2015

Revised: 3 November 2015

Accepted: 29 November 2015

${ }^{1}$ Corresponding author:

e-mail: ulrich.meyer@fli.bund.de

\begin{abstract}
Sustainability in relation to the human food chain is defined as the global balance/equilibrium between efficient use of limited natural resources (such as arable land, water, fuel, etc.), emissions (e.g., carbon dioxide, methane, nitrous oxide (laughing gas), etc.), and socio-economic and ethical aspects as a basis for the existence of future generations. Sustainability in the production of food of animal origin or edible protein necessitates efficient production. Efficiency calculations should not be limited to only the food chain links 'feed-animal-food of animal origin', but should include the entire food chain. A system has the highest efficiency or the greatest sustainability if it is impossible to improve one parameter without deterioration of one or more of the other parameters.

The present review is divided into two parts. In the first, the authors define the term sustainability and the objective of the paper. Protein of animal origin is the main topic and is the focus of the chapters regarding resource inputs in the form of arable land, water, fuel, etc., and outputs in form of animal yields and emissions such as carbon dioxide, methane and laughing gas. Carbon Footprints (CF) as an 'overall measure of emissions' are defined.
\end{abstract}

\section{Introduction}

The conversion of energy and protein from feed into food of animal origin is low and may vary from $3 \%$ (energy - beef) up to $40 \%$ (energy - dairy; protein - chicken for fattening) (Smil, 2000; Cassidy et al., 2013; Herrero et al., 2013). In some countries (e.g., USA) between 67\% (energy) and 80\% (protein) of crops are used as animal feed (Cassidy et al., 2013). The high need for feed connected with low efficiency of conversion and high emissions impose the question: Is there any need for food of animal origin?

As vegans demonstrate, there is no essential need for food of animal origin, if the human diet is supplemented with all essential nutrients. On the other hand, consumption of meat, fish, milk, eggs and other protein sources may contribute significantly to meeting human requirements for amino acids (WHO/FAO/UNU, 2007; Thompson and Amoroso, 2014; Wu et al., 2014b) and some important trace nutrients (such as $\mathrm{Ca}, \mathrm{P}, \mathrm{Zn}, \mathrm{Fe}, \mathrm{I}, \mathrm{Se}$, vitamins A, $D, E, B_{12}$ ). This is especially true for children, juveniles and women who are pregnant or lactating (Wennemer et al., 2006). Human nutritionists have recommended that about one-third of the daily protein requirements of adults ( 0.66 to 1 gram per kilogram body weight; e.g., Jackson, 2007; WHO/FAO/ UNU, 2007) should originate from protein of animal 
origin. Consequently, about $20 \mathrm{~g}$ of the daily intake of about $60 \mathrm{~g}$ protein should be of animal origin, which is lower than the present average consumption throughout the world. During the last few years, the average consumption of animal protein (excluding fish) was about $24 \mathrm{~g}$ per capita per day, ranging from $1.7 \mathrm{~g}$ (Burundi) to $69.0 \mathrm{~g}$ (USA). Overcoming these discrepancies is a challenge for the future (Smith et al., 2013a). Meat, milk and eggs provide around $13 \%$ of the energy and $28 \%$ of the protein consumed globally, with a higher share in developed countries (around $20 \%$ and $40 \%$, respectively; FAO, 2009). It is difficult to assess the protein intake from fish and other animal protein sources (e.g., insects). Avadí and Fréon (2013) estimate that half of the world's population consumed at least $15 \%$ of their animal protein from aquaculture.

Other reasons for consumption of food of animal origin include the high bioavailability of most nutrients and their considerable 'enjoyment value'. Such food is presently also considered a standardof-living indicator in many regions of the world. Further reasons for the higher demand for food of animal origin in some countries are growing incomes (Keyzer et al., 2005) and imitation of the Western lifestyle in terms of nutrition. People in many developing countries continue to consume more animal products than their countries produce. Therefore, they will continue to drive the global demand for all agricultural products, including food of animal origin (Guyomard et al., 2013). Wu et al. (2014a) estimate that with exponential growth of the global population and marked rises in meat consumption per capita, demands for animal protein are expected to increase by $72 \%$ between 2013 and 2050. Greater amounts of food of animal origin require higher plant yields and/or more area for feed production (Wirsenius et al., 2010; Smith et al., 2013b; Wu et al., 2014a) and more animals and/or higher animal yields, as well an increase in agricultural trade. Therefore, some authors propose a redefinition of agricultural yield, and agriculture in general: 'from tons to people nourished per hectare' (Kastner et al., 2012; Cassidy et al., 2013) and ask for more sustainable animal agriculture (Kebreab, 2013; FAO, 2014). In addition, livestock production is being increasingly viewed in connection with climate change (Malik et al., 2015).

On the other hand, changing eating patterns (Guyomard et al., 2012) and eating less or no livestock products, esp. meat, are often seen as possible solutions to reducing the environmental impact of animal agriculture (Pimentel and Pimentel, 2003; Baroni et al., 2007) and to reducing per capita land requirements (Peters et al., 2007; Flachowsky et al., 2015).

These developments raise concerns about the sustainability and environmental impact of animal agriculture. In summary, food security and optimal human nutrition under consideration of limited resources, increased emissions, and expected climate change can be considered major challenges for all those dealing with feed and food production and with nutrition (McKenzie and Williams, 2015). In other words, reducing and overcoming malnutrition and improving the quality of human nutrition are the main objectives and are the topics of the Global Nutrition Report 2014 (Haddad et al., 2015) and other recent papers (e.g., GASL, 2014; Garnett et al., 2015; HLPE, 2015; NRC, 2015).

\section{Definition of sustainability and objective of the paper}

The high demand for wood in Europe in the Middle Ages resulted in overexploitation of forests. Hans Carl von Carlowitz, a German administrator and scientist, drew on own experiences and was the first to formulate the so-called principle of sustainability in forestry in his Sylvicultura Oeconomica (von Carlowitz, 1713): 'The most important objective of science/management is the conservation and cultivation of forests so that sustainable utilization (not more harvest than growth) can occur, enabling the county (Saxonia, a German county) to exist in the future.'

In the discussion on sustainability raised by the Club of Rome's report, The Limits to Growth, sustainability was described for the first time as a 'condition of global equilibrium' (Meadows et al., 1972). Later, Brundtland (1987), chairman of the UN Commission on Sustainability and Sustainable Developments, introduced the term sustainability into the political vocabulary. Environmental objectives are combined with socio-economic objectives to arrive at stable societies and a balance between the economy, ecology and social aspects, as shown in Figure 1.

Later, based on the developments mentioned above, philosophers and natural scientists of various disciplines increasingly turned their attention to current global developments. The balance between Planet (global resources and emissions), People (social aspects of populations worldwide) and Profit (economic aspects, making money) in the so-called 3 P-concept (IUCN, 2004; Boonen et al., 2012) is an important prerequisite for sustainable life and development on earth. Some authors are afraid that the balance between the 3 Ps will be increasingly disturbed and a fourth ethical dimension should be 


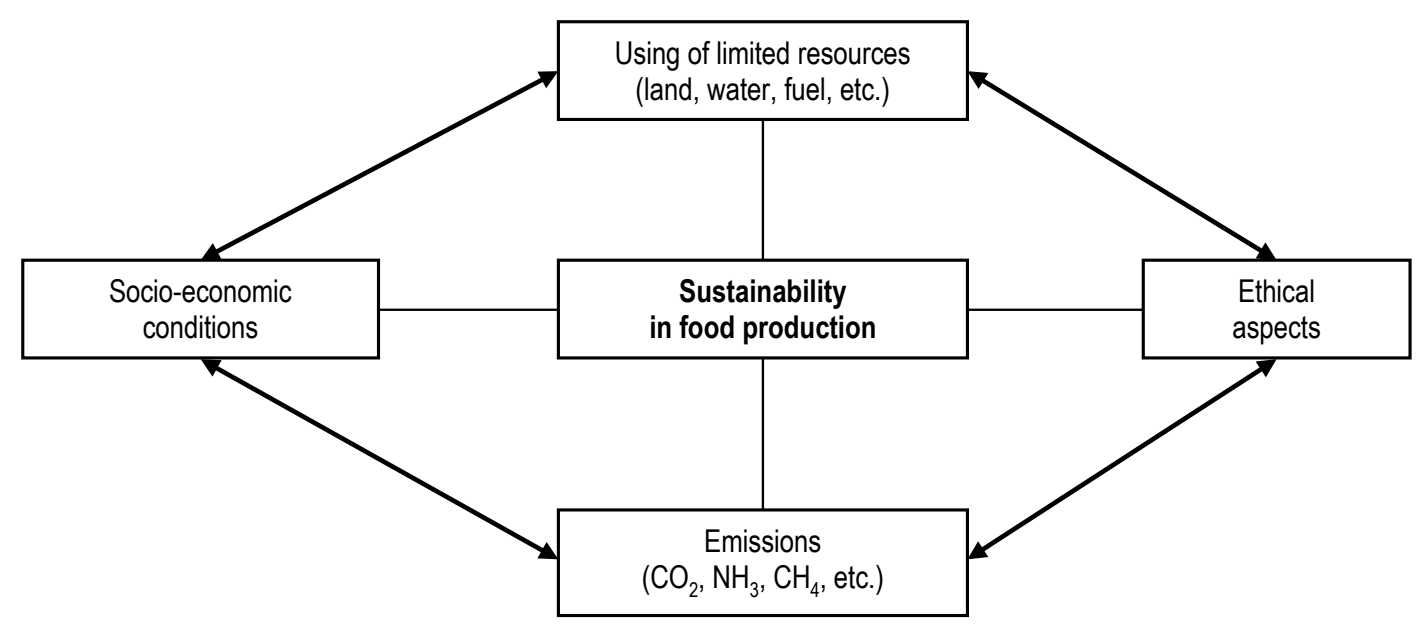

Figure 1. Sustainability as balance between using of limited natural resources, emissions, socio-economic and ethical conditions to produce food of animal origin (Flachowsky and Hachenberg, 2009).

introduced (IUCN, 2004). Profit should not and cannot be the only objective of a human being. Ethical aspects of food production should also be considered as a parameter of sustainability (Casabona et al., 2010; Viljoen and Wiskerke, 2012; Wals and Corcoran, 2012; Figure 1). We need to find a balance between careful, ethical, responsible, and sustainable use of limited resources (see above) on the one hand (Fedoroff et al., 2010; Giovannucci et al., 2012), and low emissions with local and global consequences for later generations (Foley et al., 2011) on the other hand.

Taking into account the above points, sustainable agriculture including sustainable production of food or protein of animal origin should be characterized by:

- efficient use of limited resources, improvements in farm animal productivity, and low emissions (planet, ecological aspects)

- socio-economical and ethically responsible production (economy, people)

- endowment for existence of future generations (ethical aspects).

Ruttan (1999) concluded that the transition to sustainable growth in agricultural production during the twenty-first century will take place within the context of a transition to a stable population and a possible transition to a stable level of material consumption. Global food sustainability is considered to be a great challenge for mankind (Lawrence et al., 2011).

Based on previous reports from our group (Flachowsky and Schulz, 2011; Flachowsky et al., 2013a,b), the objective of the paper is to analyse the present state of production of edible protein of animal origin, as well as the constraints and challenges for sustainable food production to 2050 .

\section{Resource demands and emissions in production of animal protein}

In the future there will be strong competition for arable land (about 1.5 billion ha; FAO, 2013a) and other non-renewable resources such as fossil carbonsources, water (e.g., Hoekstra and Chapagain, 2007; Molden et al., 2010; Schlink et al., 2010) and some minerals, such as phosphorus (Hall and Hall, 1984; Scholz and Wellmer, 2013; Table 1). Competition will be also between feed, food, fuel, fibre, flower and fun (6 Fs concept; Aerts, 2012), and areas for settlements and natural protected areas.

Table 1. Limited resources and emissions to produce food of animal origin

\begin{tabular}{ll}
\hline Limited resources & Emissions \\
\hline Land (esp. arable land) & Carbon dioxide $\left(\mathrm{CO}_{2}\right)$ \\
Water & Nitrogen compounds $\left(\mathrm{NH}_{3}, \mathrm{~N}_{2} \mathrm{O}\right.$, etc.) \\
Fuel/energy & Methane $\left(\mathrm{CH}_{4}\right)$ \\
Some minerals (e.g., $\mathrm{P})$ & \\
\hline
\end{tabular}

Thus, more attention should be paid to the need for limited natural resources per unit of animal product, expressed as footprint per product, such as Water Footprint (Mekonnen and Hoekstra, 2010), Mineral (esp. phosphorus; P) Footprint, Land (arable or total land) Footprint (Nijdam et al., 2012; Flachowsky et al., 2015). These Footprints are given in kilograms, litres or tones per unit of the product and describe the efficiency of various production processes.

Special attention has also been paid to agricultural outputs (FAO, 2006; Vermeulen et al., 2012). These include livestock husbandry, especially greenhouse gas (GHG)-relevant emissions such as $\mathrm{CO}_{2}, \mathrm{CH}_{4}$, 
$\mathrm{N}_{2} \mathrm{O}$ and others (IPCC, 2006). All of the climaterelevant emissions are incorporated into the Carbon Footprint $(\mathrm{CF})$ and its modifications, including such indicators as Ecological Footprint (EF), EcoBalances (EB), Life Cycle Assessments (LCA), or Life Cycle Impact Assessment (LCIA). Each of these terms is a comprehensive parameter for all gaseous emissions with greenhouse gas potential and are intended to draw awareness of producers and consumers (Young et al., 2010; Upham et al., 2011) to efficient use of fossil carbon sources and reduction of GHG emissions per product (de Alvarenga et al., 2012). CF and LCA are used as tools for estimating the environmental impact of products or processes. Furthermore, CF may also contribute to assessing the resource- and feed-efficiency of various regions and production systems (FAO, 2015; Flachowsky et al., 2015). All of these activities are incorporated in this indicator to contribute to more sustainable production of food of animal origin (Makkar and Ankers, 2014). Sustainable production of food of animal origin is intended to contribute to the efficient use of limited natural resources and to minimize emissions during food production along the whole food chain (Figure 2).

\section{Protein content in various foods of animal origin}

Production of protein of animal origin is one of the most important goals of animal husbandry (de Vries and de Boer, 2010; Nijdam et al., 2012). The production efficiency of food of animal origin and the related emissions can also be compared on the basis of edible protein (Flachowsky and Kamphues, 2012). The actual $\mathrm{N}$ or protein $(\mathrm{N} \times 6.25)$ content of various foods of animal origin may differ from values used for calculations in Table 3.

Quantification of protein yield varies depending on the influencing factors. For example, milk and eggs are clearly defined as food of animal origin and the yield can be measured (and expressed in kilograms, or per animal, or per day) and, therefore, it is relatively easy to use the yield of lactating or laying animals for further calculations. The edible fraction is nearly adequate to the yield since only minor fractions are not consumed by humans (e.g., colostrum, milk samples at the beginning of milking, egg membranes and shells).

It is much more difficult to quantify and characterize the yield from the animal body after slaughtering and processing. The following endpoints can be measured in meat production:

- weight gain of the animal (per day or per growing period) during the whole life span

- weight gain of animal without the content of the gastrointestinal tract

- empty body weight (or carcass weight; meat and bones; warm or cold)

- meat (empty body weight without bones)

- edible fraction (meat plus edible organs and tissues)

- edible protein (edible fractions of the carcass multiplied by their specific protein content).

All endpoints have both advantages and disadvantages. From the nutritional and scientific points of view, edible protein seems to be the most favourable measurement, but in the case of meat production its measurement is not easy and requires some analytical work (Table 2).

For practical reasons, carcass weight or weight gain (warm or cold) would be the most important

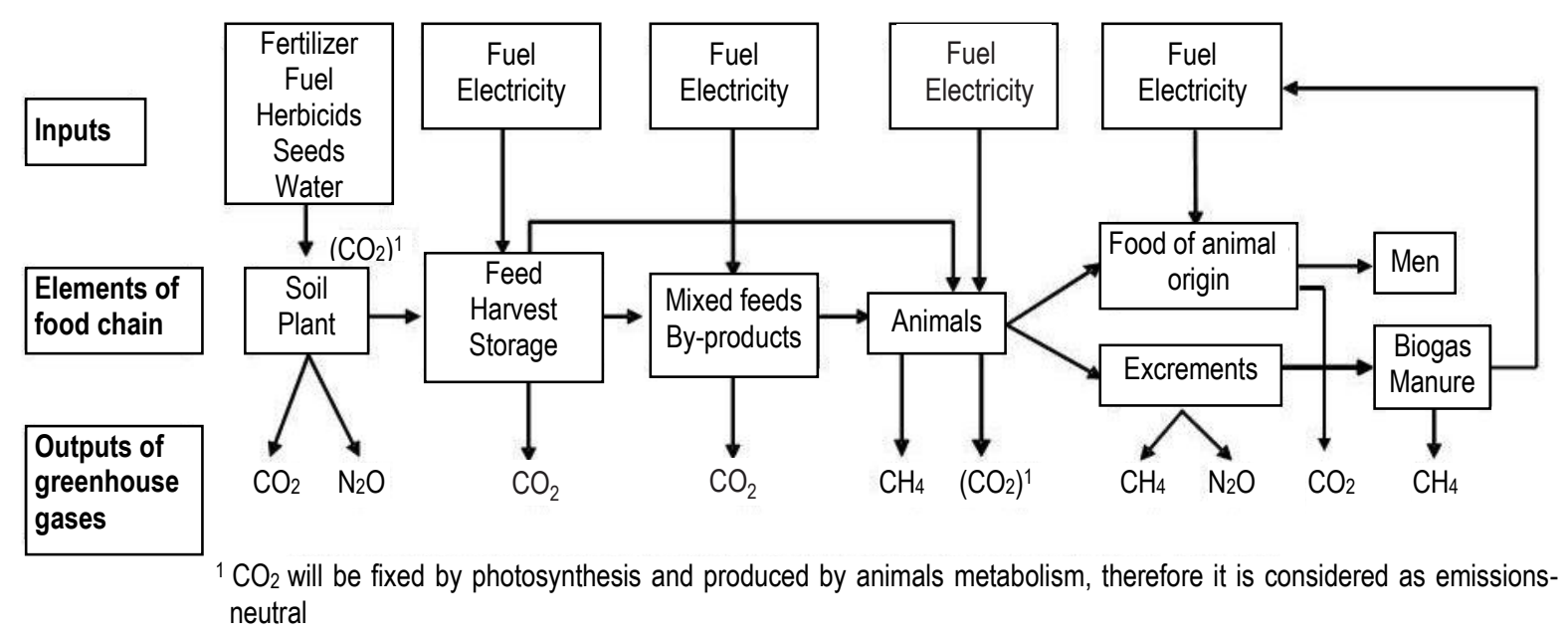

Figure 2. Substantial elements of food/supply chain to produce food of animal origin as well as selected inputs of resources and outputs of greenhouse gases (base for system boundaries); (Flachowsky and Hachenberg, 2009) 
Table 2. Advantages and disadvantages of various outputs/endpoints of animal products (Flachowsky and Kamphues, 2012)

\begin{tabular}{|c|c|c|}
\hline Animal product & Advantages & Disadvantages \\
\hline Milk, eggs & Easily measurable, almost completely edible & $\begin{array}{l}\text { Variation in protein, fat and energy yield, analyses } \\
\text { may be useful }\end{array}$ \\
\hline Body weight gain & Easily measurable & High portion of non-edible fractions in body gains \\
\hline Carcass weight & Easily measurable & Contains non-edible fractions (e.g., bones) \\
\hline Meat, edible fraction & Completely edible & Categorization and separation not easy \\
\hline Edible protein & $\begin{array}{l}\text { Most important objective of animal production. Comparison } \\
\text { of various ways and sources to produce protein of animal origin }\end{array}$ & $\begin{array}{l}\text { Categorization of various fractions as edible, } \\
\text { difficulties to measure, additional analytical work, } \\
\text { variation in } \mathrm{N} / \text { protein content }\end{array}$ \\
\hline
\end{tabular}

endpoint to measure the yield of slaughtered animals because this weight is measurable in the slaughterhouse and can be used for further calculations.

The term 'meat' is mostly used, but its actual meaning (meat with or without bones) is not clearly specified. Peters et al. (2010) introduced the term 'hot standard carcass weight' (HSCW) as the weight at the exit gate of the meat processing plant. FAO (2013b) defines meat from animals as fresh, chilled or frozen meat with bones. FAO data on meat are given in terms of dressed carcass weight excluding offals and slaughter fats. The HSCW varies between $50 \%$ and $62 \%$ of the liveweight of cattle before slaughter, and may range from $50 \%$ in the case of sheep up to $80 \%$ for turkeys (Williams et al., 2006; Peters et al., 2010). Nijdam et al. (2012) used the following killing out factors (carcass weight in \% of liveweight): $53 \%$ for beef, $75 \%$ for pork, $46 \%$ for mutton, $70 \%$ for poultry and $40 \%$ for fish. The edible meat yield (retail meat of carcass) is given by the same authors as $70 \%$ for beef, $75 \%$ for pork and mutton, $80 \%$ for poultry and $100 \%$ for fish.

Large differences exist among countries, and also among population groups within one country, when it comes to the definition of edible. Therefore it is difficult to compare results from various authors and to find the actual protein yields. The authors should clearly specify the percentages of edible fractions used for calculations (Flachowsky and Kamphues, 2012) to understand and interpret the results.

Another important factor for a reliable calculation of protein yields of food of animal origin is the protein content of edible fractions, as shown in Table 3.
The results of particular studies (Table 3), as well as values from food tables agree more or less on the ranges of the protein content of milk (between $\left.30.0-37.0 \mathrm{~g} \cdot \mathrm{kg}^{-1}\right)$, beef $\left(170-227 \mathrm{~g} \cdot \mathrm{kg}^{-1}\right)$, pork (129-240 $\left.\mathrm{g} \cdot \mathrm{kg}^{-1}\right)$, poultry $\left(182-242 \mathrm{~g} \cdot \mathrm{kg}^{-1}\right)$ and eggs $\left(110-130 \mathrm{~g} \cdot \mathrm{kg}^{-1}\right)$. The protein yields in the edible fractions of milk, meat and eggs were calculated on these data basis. For calculation of CFs for seafood from fisheries and seafood from agriculture, Nijdam et al. (2012) used 160-200 g and 170-200 g protein per kilogram of food, respectively.

\section{Resource inputs}

Limited natural resources, such as arable land, water, fuel, some minerals, etc., and virtually unlimited resources, such as sun energy, carbon dioxide and nitrogen from the air are used along the food chain (Figure 2). Sustainable production of food of animal origin requires very effective use of limited resources.

\section{Arable land}

Land, especially arable land, is one of the most important limiting factors (Bruinsma, 2009). Only a small portion of the global surface (about 13.4 billion ha) is available as arable land (more than 1.5 billion ha, i.e. about $12 \%$ of the world's land area; FAO, 2013a). This area could be extended to a certain level (about $120 \mathrm{~m}$ ha; FAO, 2013a), but some other areas cannot be used because of limited water resources, forests, urban settlements, protected for environmental reasons, topography and other reasons.

As a consequence of the limited area of arable land and the increasing population, the area of arable land

Table 3. Protein ${ }^{1}$ content of some edible land animal products/food after various authors (in g per kg edible product)

\begin{tabular}{lllllcll}
\hline Authors & Flachowsky, & GfE, 1995, & Souci & de Vries & Lesschen & Andersen, & Nijdam \\
Product/Food & 2002 & $1999,2001,2008$ & et al., 2008 & and de Boer, 2010 & et al., 2011 & 2011 & et al., 2012 \\
\hline Milk (cows) & 34 & 34 & $33.3(30.8-37.0)$ & 30 & 34.4 & 34 & 35 \\
Beef & 190 & $170-200$ & $220^{2}(206-227)$ & 190 & 206 & $206-212$ & 200 \\
Pork & 150 & $157(129-178)$ & $220^{2}(195-240)$ & 190 & 156 & $183-216$ & 200 \\
Poultry & 200 & nd & 199 & 190 & 206 & $182-242$ & 200 \\
Eggs & 120 & $121(110-124)$ & 125 & 130 & 119 & 125 & 130 \\
\hline
\end{tabular}

${ }^{1} \mathrm{~N}$ content $\times 6.25,{ }^{2}$ muscles only, nd - no data 


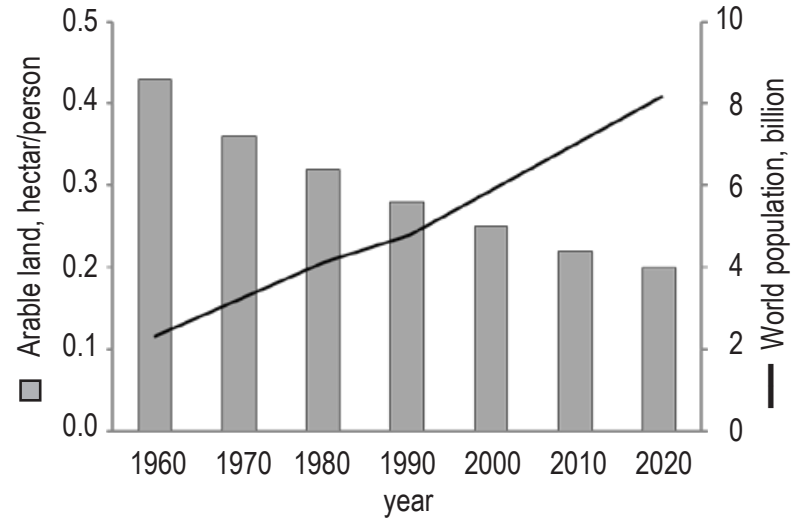

Figure 3. Development of world population and arable land per inhabitant between 1960 and 2020

per inhabitant decreased from about 0.45 ha (1960) to about 0.25 ha (2010) and will further decrease to below 0.20 ha per inhabitant after 2020 (Figure 3).

The increasing area allotted for biofuel production, organic farming, settlements, natural protected areas and other purposes also has consequences for feed and food production and for competition for land (Smith et al., 2010). Because of the high demand for limited resources, attention has been paid to the area required for animal production. High yields of available organic plant matter are important prerequisites for decreasing the amount of land needed and used to produce a certain amount of food of animal origin (Havlik et al., 2013). Only several authors dealing with land use (also described as land or area footprint for food of animal origin) (Peters et al., 2007; de Vries and de Boer, 2010; Nijdam et al., 2012), have distinguished areas (mostly arable land) that can also be used for other purposes (6 Fs concept) and typical feed areas (grassland or perennial crops). It can be expected that in view of the worldwide increase in demand for land and in emissions, public interest in the use of limited resources and in the high CF (emissions) of food of animal origin will not diminish in the near future. $\mathrm{Ar}$ able land use per unit of product or protein of animal origin depends mainly on animal species and category, plant and animal yields, use of grassland, as well as the proportion of co-products in the rations (Smith et al., 2013b).

\section{Water}

Water is one of the most limiting factors for food production (Molden, 2007; Gordon et al., 2010). About $70 \%$ of water used from rivers, lakes or groundwater is exploited in agriculture, mainly for irrigation. Nearly $20 \%$ of arable land (about $300 \mathrm{~m} \cdot \mathrm{ha}^{-1}$ ) is irrigated and produces about $40 \%$ of global plant yields (FAO, 2014). The competition for water for various food systems will be increased as
Table 4. Water footprints for food of plant and animal origin by various authors

\begin{tabular}{lc}
\hline Feed or food & Water footprint, $\mathrm{l} \cdot \mathrm{kg}^{-1}$ \\
\hline Cereals & 1644 \\
Oil seeds & 2364 \\
Potatoes & 250 \\
Cow milk & 1020 \\
Eggs & 3265 \\
Poultry & 4325 \\
Pork & 5988 \\
Beef & 15415 \\
\hline
\end{tabular}

the population grows (Strzepek and Boehlert, 2010). The water used in the production of commodities (such as feeds) is called virtual water (Hoekstra and Hung, 2005). The international trade of feeds brings along international flows of virtual water. Therefore, feed imports may be also considered as water imports. About 13\% of water used for crop production in the world is not used for domestic consumption, but for export in virtual form (Hoekstra and Hung, 2005). Water supply, water deficiency and climate change are strongly connected with sustainability and food security (Hanjra and Qureshi, 2010; Allouche, 2011). The water demand (Molden et al., 2010) per food of plant or animal origin is called the 'Water Footprint' (WF; Hoekstra and Chapagain, 2007; GerbensLeenes et al., 2009). WF shows the amount of water necessary to produce a certain amount of food of plant or animal origin (Table 4).

The direct water intake by livestock is very small compared with the water demand for feed and food production (e.g., Meyer et al., 2004, 2006; Schlink et al., 2010).

\section{Fossil energy}

Fossil energy in the form of oil, gas, coal and other energy sources should also be considered as limited and non-renewable global resources. Energy is an important input in many elements of the food chain, such as soil and plant cultivation, fertilizing, harvesting, transportation, processing of harvested products, but also for production of fertilizers and in animal husbandry (Bockisch et al., 2000; Figure 2).

\section{Outputs}

The most important objective of keeping animals is to produce food or edible protein of animal origin, such as milk, meat, eggs and food from aquaculture for human nutrition. Apart from this objective, animals and animal products are also used for many other purposes, such as draught and sport animals, to produce manure, heating material, skins 
Table 5. Influence of animal species, categories and performances on yield of edible protein

\begin{tabular}{|c|c|c|c|c|c|c|c|}
\hline $\begin{array}{l}\text { Animal } \\
\text { body weight }\end{array}$ & $\begin{array}{l}\text { Performance, } \\
\text { per day }\end{array}$ & $\begin{array}{l}\text { Dry matter } \\
\text { intake, } \\
\text { kg per day }\end{array}$ & $\begin{array}{l}\text { Roughage } \\
\text { to concentrate } \\
\text { ratio, } \\
\text { on DM basis, \% }\end{array}$ & $\begin{array}{l}\text { Edible fraction, } \\
\% \text { of product or } \\
\text { body mass }\end{array}$ & $\begin{array}{l}\text { Protein in edible } \\
\text { fraction, g per kg } \\
\text { fresh matter }\end{array}$ & $\begin{array}{l}\text { Edible } \\
\text { protein, } \\
\text { g per day }\end{array}$ & $\begin{array}{l}\text { Edible protein, } \\
\text { g per kg body } \\
\text { weight }\end{array}$ \\
\hline \multirow[t]{3}{*}{ Dairy cow, 650 kg } & 10 kg milk & 12 & $90 / 10$ & \multirow[t]{3}{*}{95} & \multirow[t]{3}{*}{34} & 323 & 0.5 \\
\hline & 20 kg milk & 16 & $75 / 25$ & & & 646 & 1.0 \\
\hline & 40 kg milk & 25 & $50 / 50$ & & & 1292 & 2.0 \\
\hline \multirow[t]{2}{*}{ Dairy goat, 60 kg } & 2 kg milk & 2.0 & $80 / 20$ & \multirow[t]{2}{*}{95} & \multirow[t]{2}{*}{36} & 68 & 1.1 \\
\hline & $5 \mathrm{~kg}$ milk & 2.5 & $50 / 50$ & & & 170 & 2.8 \\
\hline \multirow[t]{3}{*}{ Beef cattle, $350 \mathrm{~kg}$} & $500 \mathrm{~g}^{1}$ & 6.5 & $95 / 5$ & \multirow[t]{3}{*}{50} & \multirow[t]{3}{*}{190} & 48 & 0.14 \\
\hline & $1000 \mathrm{~g}^{1}$ & 7.0 & $85 / 15$ & & & 95 & 0.27 \\
\hline & $1500 \mathrm{~g}^{1}$ & 7.5 & $70 / 30$ & & & 143 & 0.41 \\
\hline \multirow{3}{*}{$\begin{array}{l}\text { Growing/fattening pig } \\
80 \mathrm{~kg}\end{array}$} & $500 \mathrm{~g}^{1}$ & 1.8 & $20 / 80$ & \multirow[t]{3}{*}{60} & \multirow[t]{3}{*}{150} & 45 & 0.56 \\
\hline & $700 \mathrm{~g}^{1}$ & 2.0 & $10 / 90$ & & & 63 & 0.8 \\
\hline & $1000 \mathrm{~g}^{1}$ & 2.2 & $0 / 100$ & & & 81 & 1.0 \\
\hline \multirow[t]{2}{*}{ Broiler, $1.5 \mathrm{~kg}$} & $40 \mathrm{~g}^{1}$ & 0.07 & $10 / 90$ & \multirow[t]{2}{*}{60} & \multirow[t]{2}{*}{200} & 4.8 & 3.2 \\
\hline & $60 \mathrm{~g}^{1}$ & 0.08 & $0 / 100$ & & & 7.2 & 4.8 \\
\hline \multirow[t]{3}{*}{ Laying hen, $1.8 \mathrm{~kg}$} & $50 \%^{2}$ & 0.10 & $20 / 80$ & \multirow[t]{3}{*}{95} & \multirow[t]{3}{*}{120} & 3.4 & 1.9 \\
\hline & $70 \%{ }^{2}$ & 0.11 & $10 / 90$ & & & 4.8 & 2.7 \\
\hline & $90 \%{ }^{2}$ & 0.12 & $0 / 100$ & & & 6.2 & 3.4 \\
\hline
\end{tabular}

${ }^{1}$ daily weight gain, ${ }^{2}$ laying performance

and other useable by-products. In the following section (Food of animal origin) attention will be paid to food of animal origin or edible protein as the most important yield. Part 1, Emissions deals with emissions as the second part of outputs, e.g., carbon dioxide $\left(\mathrm{CO}_{2}\right)$, methane $\left(\mathrm{CH}_{4}\right)$, and laughing gas $\left(\mathrm{N}_{2} \mathrm{O}\right)$, followed by the calculation of CFs and listing of CFs for various foods of animal origin.

\section{Food of animal origin}

The $\mathrm{N}$ or protein content of various foods of animal origin may vary from values used for the calculations in Table 3. Taking into account the various influencing factors such as animal performance, feeding, edible fractions and protein content of the edible fractions, the yields of edible protein per day and per kilogram body weight of animals is given in Table 5 . There are large differences in animal protein yield per animal per day or per kilogram body weight and day depending on animal species and categories, as well as their performances and the fractions considered as edible.

The highest protein yields per kilogram body weight are in growing broilers and in laying and lacctating animals, and the lowest in growing/fattening ruminants (Table 5). Higher animal yields increase the yield of edible protein.

\section{Emissions}

Emissions from agriculture should also be considered in the context of sustainability (Figure 1). Gases with greenhouse potential may have long- term environmental effects (IPCC, 2006). Emissions generated by production of food of animal origin can be also compared on the basis of edible protein. Production of this food comprises various processes accompanied by GHG emissions, including soil cultivation and fertilization, harvesting, storing and processing feed, as well as animal keeping. According to the IPCC (2006), the human food chain (Figure 2) also generates GHG emissions and processes in a managed ecosystem. The most important GHG emissions associated with animal husbandry are discussed below.

Carbon dioxide $\left(\mathrm{CO}_{2}\right)$. Direct carbon dioxide emission from animals can be considered emissionneutral. The $\mathrm{CO}_{2}$ will be fixed by photosynthesis of plants and excreted by the animals as a result of animal metabolism (Figure 2). Nonetheless, $\mathrm{CO}_{2}$ emission must be seen along the whole food chain (including the food industry, transport, trade and households) and based on burning of fossil carbon during feed production and land-use changes (LUC; Hergoualc'h and Verchot, 2011; MacLeod et al., 2013). In general, other than $\mathrm{CO}_{2}$, GHGs such as methane $\left(\mathrm{CH}_{4}\right)$ and nitrous oxide $\left(\mathrm{N}_{2} \mathrm{O}\right)$ come directly from animals or from animal manure practices.

Methane $\left(\mathrm{CH}_{4}\right)$ is emitted under anaerobic conditions from the enteric fermentation in the digestive tract of animals, mainly in the rumen, but also during manure management. The excess of hydrogen produced during anaerobic fermentation in the 
rumen is utilized in various reduction processes. The last step in the formation of methane is catalysed by methyl-coenzyme $\mathrm{M}$ reductase that reduces $\mathrm{CO}_{2}$ to $\mathrm{CH}_{4}$ in hydrogenotropic methanogenic archaea (Attwood and McSweeney, 2008). Details about enteric methane production are described in many papers (e.g., Bannink et al., 2008; Jouany, 2008; Beauchemin et al., 2009) and prediction equations have been given (e.g., Hristov et al., 2013a; Ricci et al., 2013). Reduction potentials are analysed in Part 2, Reduction of emissions. Methane contributes not only to the greenhouse effect, since between $2 \%$ and $12 \%$ of the gross energy ingested by ruminants can be lost in methane (Johnson and Johnson, 1995). This energy could potentially be used by the animals for growth and lactation (Niemann et al., 2011). The methane emissions from manure management can be considerably high (Hristov et al., 2013b; Montes et al., 2013), especially if the excreta are stored under anaerobic conditions.

Nitrous oxide (laughing gas, $\mathrm{N}_{2} \mathrm{O}$ ). Animals do not excrete nitrous oxide directly, but it can be formed in manure depending on the storage conditions and following application to land (Hristov et al., 2013b; Montes et al., 2013). $\mathrm{N}_{2} \mathrm{O}$ is produced mainly in soils by microbial nitrification (the oxidation of ammonium $\mathrm{NH}_{4}^{+}$to nitrate $\mathrm{NO}_{3}^{-}$) and denitrification (reduction of $\mathrm{NO}_{3}^{-}$to $\mathrm{N}_{2}$; Stevens et al., 1997). These microbial processes depend on the temperature, moisture content and oxidation status of the environment. High N-fertilization and soil compaction increase $\mathrm{N}_{2} \mathrm{O}$ emissions. Since 1750, the tropospheric concentration of $\mathrm{N}_{2} \mathrm{O}$ has increased from 270 to $320 \mathrm{ppb}$. Details about $\mathrm{N}_{2} \mathrm{O}$ production and emission from the soil have been described by numerous authors (e.g., Lampe et al., 2006; Bessou et al., 2010) and will be considered further in the present paper.

Calculations of carbon footprints (CF). Carbon footprints are defined as the total amount of GHG emissions associated with a product along its supply (human food) chain: plant production - harvesting - storing - treatment - feed preparation - feeding of food-producing animals - preparation of food (milk, meat, eggs, etc.) - distribution - market households (Figure 2). Agriculture and especially animal husbandry are considered important GHG sources because of the high greenhouse gas potential of their emissions (e.g., $\mathrm{CO}_{2} \times 1 ; \mathrm{CH}_{4} \times 23$ and $\mathrm{N}_{2} \mathrm{O} \times 296$; IPCC, 2006). CFs take into account the GHG potential of climate-relevant gases and are expressed in $\mathrm{CO}_{2 \text {-eq }}$ per gram or kilogram of product (Opio et al., 2013).

The number of publications reporting studies on this topic rose from one to two per year in 1998-2000 to about 20 studies per year during recent years (Avadí and Fréon, 2013). The studies dealt with calculations of CFs for nearly all types of food of animal origin (summaries by Williams et al., 2006; Gerber et al., 2013; MacLeod et al., 2013; Opio et al., 2013; Flachowsky, 2015). Life Cycle Assessments (LCA), such as CF calculation for food of animal origin, depend on many factors, such as animal species and categories, animal yields, system boundaries, and endpoints of animal production. Various authors have calculated CFs for agriculture in general, but also for separate segments.

The public's interest in CFs is usually centred on global warming and possible climate changes (IPCC, 2006, 2014). Consequences of LUC, as a change of forest into cropland or pasture, for $\mathrm{CF}$ calculations should also be considered (Havlik et al., 2013; Smith et al., 2013b), but in some cases the values are not known or not taken into account in the calculations (e.g., import of feeds).

A number of factors (e.g., plant yield, animal species and performances, type of production) cannot be ignored when the greenhouse gas potential of the various gases (see above) to derive CF is assessed and the values along the food chain are compared. The origins of the most important GHG, such as carbon dioxide, methane and nitrous oxide, have been shown by the FAO (2015) recently.

Carbon footprints for edible protein. Based on above mentioned values, emissions per kilogram edible protein are given in Table 6. Nijdam et al. (2012) give a range in $\mathrm{CF}$ between 5 and $750 \mathrm{~kg} \mathrm{CO}_{2 \text {-eq }} \cdot \mathrm{kg}^{-1}$ protein. These extremes do not represent large production volumes, but they could be measured under specific conditions (Table 6). Higher portions of edible fractions or higher protein contents may increase the protein yield and reduce the CF per unit of edible protein. At high levels of animal performance there are remarkable differences among $\mathrm{CO}_{2}$ emissions related to $1 \mathrm{~kg}$ of protein from food of different origin, increasing from eggs and poultry meat $<$ pork $<$ milk $<$ beef (Table 6).

Nutrition may influence the CF of food of animal origin. In the case of ruminants, higher amounts of concentrate are required with higher animal yields. The proportion of co-products (Bockisch et al., 2000; Makkar, 2012) used as animal feeds has not only nutritional implications, but it also affects the results of calculations of land use (Vandehaar, 1998). Improvements in farm animal productivity will not only increase feed efficacy, but it will also reduce the emissions per animal product (Table 6). Allocation methods are used for animal products whenever the system under study generates more than one saleable 
Table 6. Influence of animal species, categories and performances on emissions (per kg of edible protein)

\begin{tabular}{|c|c|c|c|c|c|c|c|}
\hline \multirow{2}{*}{$\begin{array}{l}\text { Animal } \\
\text { body weight }\end{array}$} & \multirow{2}{*}{$\begin{array}{l}\text { Performance, } \\
\text { per day }\end{array}$} & \multirow{2}{*}{$\begin{array}{l}\text { N-excretion, } \\
\% \text { of intake }\end{array}$} & \multirow{2}{*}{$\begin{array}{l}\text { Methane emission, } \\
\text { g per day }{ }^{3}\end{array}$} & \multicolumn{4}{|c|}{ Emissions in $\mathrm{kg}$ per $\mathrm{kg}$ of protein } \\
\hline & & & & $P$ & $\mathrm{~N}$ & $\mathrm{CH}_{4}{ }^{3}$ & $\mathrm{CO}_{2 \text {-eq }}$ \\
\hline \multirow[t]{3}{*}{ Dairy cow, $650 \mathrm{~kg}$} & 10 kg milk & 75 & 310 & 0.10 & 0.65 & 1.0 & 30 \\
\hline & 20 kg milk & 70 & 380 & 0.06 & 0.44 & 0.6 & 16 \\
\hline & 40 kg milk & 65 & 520 & 0.04 & 0.24 & 0.4 & 12 \\
\hline \multirow[t]{2}{*}{ Dairy goat, $60 \mathrm{~kg}$} & $2 \mathrm{~kg}$ milk & 75 & 50 & 0.08 & 0.5 & 0.8 & 20 \\
\hline & $5 \mathrm{~kg}$ milk & 65 & 60 & 0.04 & 0.2 & 0.4 & 10 \\
\hline \multirow[t]{3}{*}{ Beef cattle, $350 \mathrm{~kg}$} & $500 \mathrm{~g}^{1}$ & 90 & 170 & 0.30 & 2.3 & 3.5 & 110 \\
\hline & $1000 \mathrm{~g}^{1}$ & 84 & 175 & 0.18 & 1.3 & 1.7 & 55 \\
\hline & $1500 \mathrm{~g}^{1}$ & 80 & 180 & 0.14 & 1.0 & 1.2 & 35 \\
\hline \multirow[t]{3}{*}{ Growing/fattening pig, $80 \mathrm{~kg}$} & $500 \mathrm{~g}^{1}$ & 85 & 5 & 0.20 & 1.0 & 0.12 & 16 \\
\hline & $700 \mathrm{~g}^{1}$ & 80 & 5 & 0.12 & 0.7 & 0.08 & 12 \\
\hline & $900 \mathrm{~g}^{1}$ & 75 & 5 & 0.09 & 0.55 & 0.05 & 10 \\
\hline \multirow[t]{2}{*}{ Broilers, $1.5 \mathrm{~kg}$} & $40 \mathrm{~g}^{1}$ & 70 & Traces & 0.04 & 0.35 & 0.01 & 4 \\
\hline & $60 \mathrm{~g}^{1}$ & 60 & & 0.03 & 0.25 & 0.01 & 3 \\
\hline \multirow[t]{3}{*}{ Laying hen, $1.8 \mathrm{~kg}$} & $50 \%{ }^{2}$ & 80 & Traces & 0.12 & 0.6 & 0.03 & 7 \\
\hline & $70 \%{ }^{2}$ & 65 & & 0.07 & 0.4 & 0.02 & 5 \\
\hline & $90 \%{ }^{2}$ & 55 & & 0.05 & 0.3 & 0.02 & 3 \\
\hline
\end{tabular}

${ }^{1}$ daily weight gain, ${ }^{2}$ laying performance, ${ }^{3} \mathrm{CH}_{4}$ - emission depending on composition of diet

output (e.g., milk and meat; Zehetmeier et al., 2012; Roer et al., 2013). Zehetmeier et al. (2012) calculated CFs equalling 1.35 and $0.98 \mathrm{~kg} \mathrm{CO}_{2-\mathrm{eq}} \cdot \mathrm{kg}^{-1}$ milk of cows producing 6000 or $10000 \mathrm{~kg}$ milk per year, respectively. In the case of lower milk yield, beef was produced as a by-product of calves from dairy cows with a CF of $5.58 \mathrm{~kg}$; but in the case of higher milk yields, beef cows were needed to produce sufficient beef and the CF increased to $14.62 \mathrm{~kg} \mathrm{CO}_{2 \text {-eq }} \cdot \mathrm{kg}^{-1}$ beef. This example shows the complexity of such calculations which require a multi-functional approach.

Apart from the factors mentioned above, excrement management (Hristov et al., 2013b; Montes et al., 2013), processing of food of animal origin, transportation, marketing and kitchen work may also influence CF per food and sustainability of production (Figure 2).

Carbon footprints of aquaculture and other protein sources. Aquaculture is an increasingly important way to produce food protein of animal origin. Recently, some authors tried to determine the CFs of various forms of aquaculture. Mungkung et al. (2013) carried out a case study of combined aquaculture systems for carp and tilapia, including fingerling production in hatcheries, fish rearing in cages, and transport of feed and harvested fish to markets.

Avadí and Fréon (2013) reviewed 16 LCA studies on fisheries and compared the following aspects: scope and system boundaries, functional unit allocation strategies for co-products, conventional and fishery-specific impact categories, fuel use, impact assessment methods, level of detail of inventories, normalization of results, as well as sensitivity and uncertainty analyses. Fishery-specific impact categories and fuel use in fishing operations were identified as the main contributors to environmental impact. Nijdam et al. (2012) analysed 18 and 11 studies for seafood from fisheries and aquaculture, respectively. The authors reported CF values between 1 and 86 for seafood from fisheries and between 3 and $15 \mathrm{~kg} \mathrm{CO}$ 2-eq $\mathrm{kg}^{-1}$ for seafood from agriculture. These authors, as well Avadí and Fréon (2013), raise the need for standardization of fisheries LCA research for further studies on sustainability of seafood and fisheries-based aquafood.

Apart from milk, meat, eggs and fish, other sources of protein of animal origin, such as wild animals and insects, are also consumed by humans. Nothing is known about the CF of food from wild animals.

Insects and their larvae are used in many countries (see Part 2, Potential of insects and other protein sources). Some authors analysed the feed conversion (Gahukar, 2011), land use (Oonincx and de Boer, 2012; van Huis, 2013) and greenhouse gas emissions of insects (Oonincx et al., 2010; Oonincx and de Boer, 2012) and compared their data with appropriate values of traditional food-producing animals. The feed conversion of insects under laboratory conditions should be better than in traditional animals and lower CFs are expected (Oonincx et al., 2010; Oonincx and de Boer, 2012). Recently, Lundy and Parrella (2015) suggest that the laboratory-scale 
Table 7. Carbon footprints (CF) of protein of food of animal origin according to several live cycle assessment studies

\begin{tabular}{lcc}
\hline Protein source (studies) & $\mathrm{kg} \mathrm{CO}_{2-\mathrm{eq}}$ per kg of product & $\mathrm{kg} \mathrm{CO}_{2 \text {-eq }}$ per $\mathrm{kg}$ of protein \\
\hline Cow milk $(n=14)$ & $1-2$ & $28-43$ \\
Beef, intensive system $(n=11)$ & $9-42$ & $45-210$ \\
Meadow, suckler herds $(n=8)$ & $23-52$ & $114-250$ \\
Extensive pastoral systems $(n=4)$ & $12-129$ & $58-643$ \\
Mutton and lamb $(n=5)$ & $10-150$ & $51-750$ \\
Pork $(n=11)$ & $4-11$ & $20-55$ \\
Poultry $(n=5)$ & $2-6$ & $10-30$ \\
Eggs $(n=5)$ & $2-6$ & $15-42$ \\
Seafood from fisheries $(n=18)$ & $1-86$ & $4-540$ \\
Seafood from aquaculture $(n=11)$ & $3-15$ & $4-75$ \\
\hline
\end{tabular}

rearing of crickets (Acheta domestica) was influenced by the type of diet used. The authors concluded that crickets reared on poultry feed showed similar feed conversion and emissions as poultry. More studies under field conditions are necessary to allow a conclusive evaluation of the sustainability of insects as protein-rich feed and food sources (EFSA, 2015).

Nijdam et al. (2012) analysed 52 LCA studies (Table 7) and summarized the CF per kilogram product and per kilogram edible protein of animal origin. The results indicate that large differences exist among the studies and products. The outcomes for milk, pork, poultry and eggs show much more homogeneity than those for beef, mutton, lamb and seafood. This is largely because of the very wide variety in production systems of the last food groups. Meat from non-ruminants has lower $\mathrm{CFs}$ than those from ruminants because methane is the main contributor to the $\mathrm{CF}$ in ruminants.
Because the values for feed production and processing are too low (Table 5), most values shown in Table 6 are considerably lower than the data given in Table 7.

\section{Conclusions}

Sustainability of the production of food of animal origin or edible protein means the efficient use of limited resources as feed and low emissions per product of animal origin/edible protein. Such calculations should not only include the food chain links 'feed - animal - food of animal origin', but the entire food chain. A system has the highest efficiency or the largest sustainability if it is impossible to improve one parameter without deterioration of one or more of the other parameters.

\section{References: see Part 2}

